\title{
KNOWLEDGE, ATTITUDES AND PRACTICES OF LOCAL PEOPLE ON SIBERUT ISLAND (WEST-SUMATRA, INDONESIA) TOWARDS PRIMATE HUNTING AND CONSERVATION
}

\author{
Marcel Quinten ${ }^{1}$, Farquhar Stirling ${ }^{2}$, Stefan Schwarze ${ }^{3}$, Yoan Dinata ${ }^{4}$ \& Keith Hodges ${ }^{5}$ \\ 1,5 Reproductive Biology Unit, German Primate Center, Goettingen 37077, Germany \\ ${ }^{1,5}$ Siberut Conservation Programme, Pola Mas, Padang 25122, Indonesia \\ 2,4 Fauna \& Flora International, Indonesia Programme, Jakarta 12550, Indonesia \\ ${ }^{3}$ Department of Agricultural Economics and Rural Development, University of Goettingen, Goettingen 37073, Germany \\ ${ }^{1}$ marcel.quinten-dpz@gmx.de (corresponding author), ${ }^{2}$ f.stirling49@gmail.com, \\ ${ }^{3}$ s.schwarze@agr.uni-goettingen.de, ${ }^{4}$ yoan7dinata@gmail.com, ${ }^{5}$ khodges@dpz.eu
}

\begin{abstract}
The Mentawai Archipelago (West-Sumatra, Indonesia) harbours a wealth of endemic animals and plants including six unique primate species, all threatened by habitat loss and hunting. Although hunting is known to be widespread, little systematic work has been carried out to examine its scale and impact on Mentawai's primate populations. Here we report an island-wide survey carried out on Siberut, the archipelago's largest island, to assess hunting behaviour with respect to the four locally-occurring primate species, as well as the attitudes of indigenous inhabitants to resource utilization. Face-to-face interviews were conducted in mid-2012 with 390 respondents from 50 villages using a structured questionnaire. Overall, ca. one quarter of the respondents (24\%) are still active hunters, generally targeting Simias concolor (77\%), Macaca siberu (71\%) and Presbytis siberu (68\%); Hylobates klossii is rarely hunted (3\%). Mostly, a single animal is captured per hunt, with average numbers per three months ranging from 1.9-2.3 individuals (for $S$. concolor, $M$. siberu and $P$. siberu). We found that in many aspects our data did not differ between the protected area (Siberut National Park) and the rest of the island, although hunting was significantly more prevalent within the protected area's boundaries. Our approximation of annual offtake leads us to conclude that no less than 4,800 primates are taken every year ( $\min .6 .4 \%$ of the population). We provide recommendations on how to reduce hunting as a driver for population decline.
\end{abstract}

Keywords: Bushmeat, Hylobates klossii, Macaca siberu, offtake, population decline, Presbytis siberu, Siberut, Simias concolor.
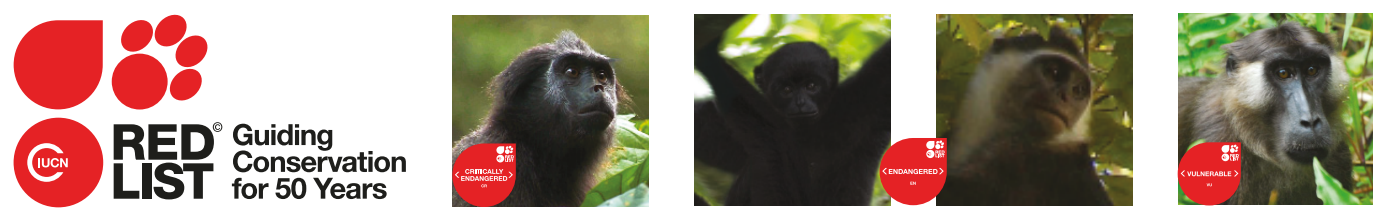

DOI: http://dx.doi.org/10.11609/JoTT.03963.6389-98

Editor: Tony Whitten, Fauna \& Flora International, Cambridge, UK.

Date of publication: 26 October 2014 (online \& print)

Manuscript details: Ms \# 03963 | Received 10 March 2014 | Final received 05 September 2014 | Finally accepted 19 September 2014

Citation: Quinten, M., F. Stirling, S. Schwarze, Y. Dinata \& K. Hodges (2014). Knowledge, attitudes and practices of local people on Siberut Island (West-Sumatra, Indonesia) towards primate hunting and conservation. Journal of Threatened Taxa 6(11): 6389-6398; http://dx.doi.org/10.11609/JoTT.o3963.6389-98

Copyright: (c) Quinten et al. 2014. Creative Commons Attribution 4.0 International License. JoTT allows unrestricted use of this article in any medium, reproduction and distribution by providing adequate credit to the authors and the source of publication.

Funding: This study was made possible by the joint financial contributions of the Mohamed bin Zayed Species Conservation Fund, the German Primate Center and the US Fish and Wildlife Service.

Competing Interest: The authors declare no competing interests.

For Author Contribution, Author Details and Bahasa Indonesia Abstract see end of this article.

Acknowledgements: We thank the German Primate Center, the Siberut Conservation Programme and Fauna \& Flora International Indonesia Programme for their joint efforts to realize this project, Perkumpulan Siberut Hijau (PASIH) for organizing local travel and logistics and the survey team for their help and dedication to collect the field data, specifically Linus, Ismail, Silvanus, Mateus, Alysius, Vincent, Fernando, Badul, Yohannes, Ricky, Jhoni and Damianus. Furthermore, we thank David McCallum for support with statistics and three anonymous reviewers for their help with improving the initial manuscript.
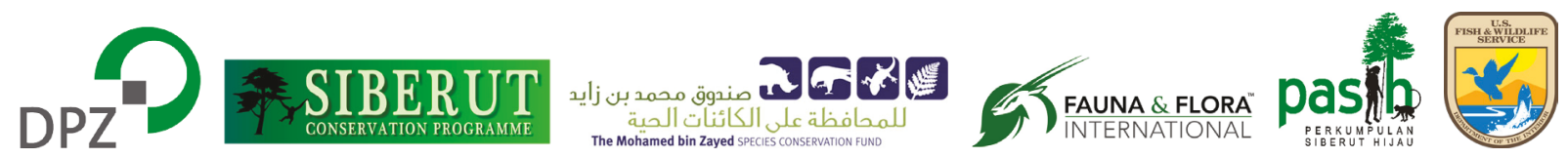


\section{INTRODUCTION}

The Mentawai Archipelago, situated approximately $150 \mathrm{~km}$ off the west coast of Sumatra in Indonesia and comprising the four main islands of Siberut, Sipora, North- and South Pagai, is well known for its unusual biological richness and species endemism (WWF 1980; Fuentes 1996). Covering just over $6,000 \mathrm{~km}^{2}$ (BPSKKM 2011), the island chain harbours a wealth of endemic animals and plant species - of the mammals alone, nearly $60 \%$ are endemic to the region at some level (cf. Wilson \& Reader 2005; IUCN 2014). Amongst these are six species of primates, namely the Siberut- and the Pagai Island Macaque (Macaca siberu and M. pagensis), both locally known as 'Bokkoi', the Siberut- and the Mentawai Langur or 'Joja' (Presbytis siberu and P. potenziani), the Pig-tailed Snub-nosed Langur or 'Simakobu' (Simias concolor), and Kloss' Gibbon or 'Bilou' (Hylobates klossii) (Images 1-4).
Collectively, this represents one of the highest rates of primate endemism per unit area anywhere (WWF 1980) and highlights the importance of the Mentawai Islands in the context of global primate conservation.

Despite the conservation significance of the Mentawai primates, their populations are not well protected and all are considered to be in decline (Whittaker 2006). They are currently classified in the IUCN Red List (IUCN 2014) either as Vulnerable (M. siberu), Endangered (H. klossii and P. siberu [as P. potenziani siberu]) or Critically Endangered (M. pagensis, S. concolor and $P$. potenziani [as $P$. potenziani potenziani]); the Pig-tailed Langur also belongs to the world's 25 most endangered primates (Mittermeier et al. 2012). As in other tropical forest regions (Bodmer et al. 1997; Dela 2011), the two main factors threatening primates in the Mentawais are habitat loss and hunting. Commercial logging, land clearance and non-sustainable agricultural practices

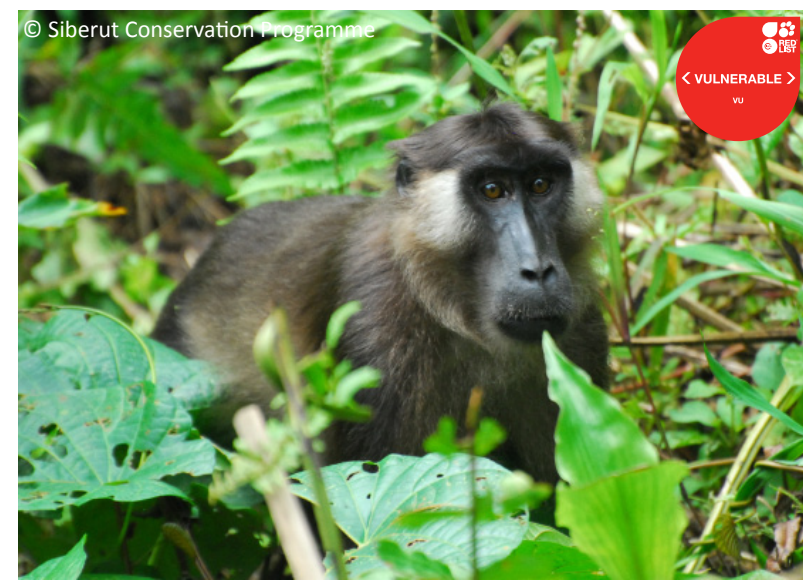

Image 1. Siberut Island Macaque Macaca siberu (2010)

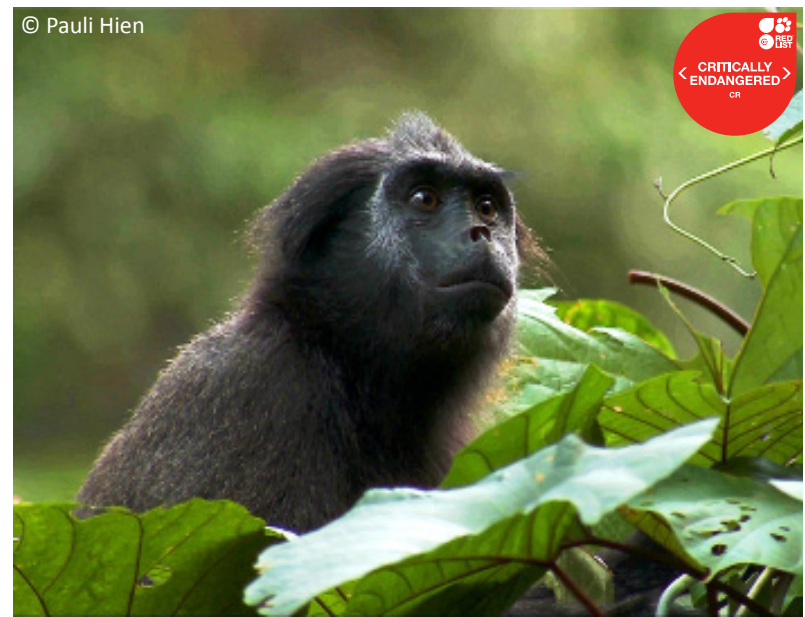

Image 3. Pig-tailed Snub-nosed Langur Simias concolor (2010)

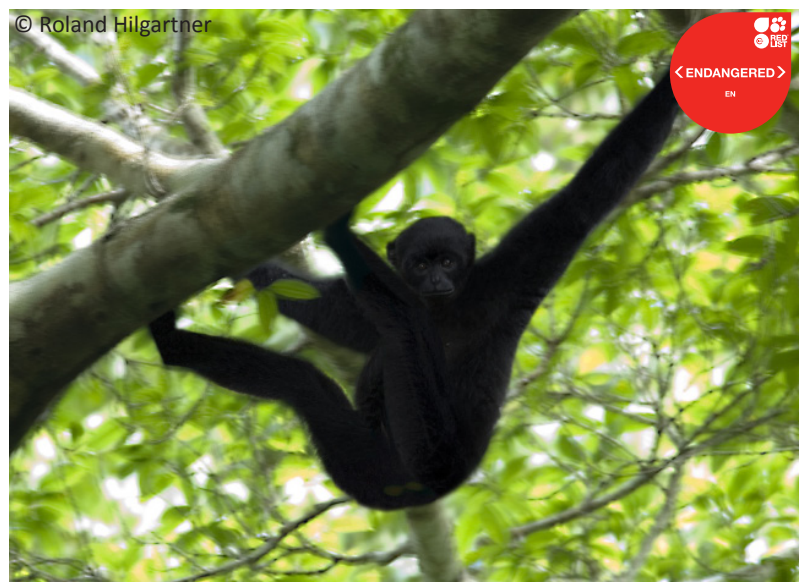

Image 2. Kloss' Gibbon Hylobates klossii (2007)

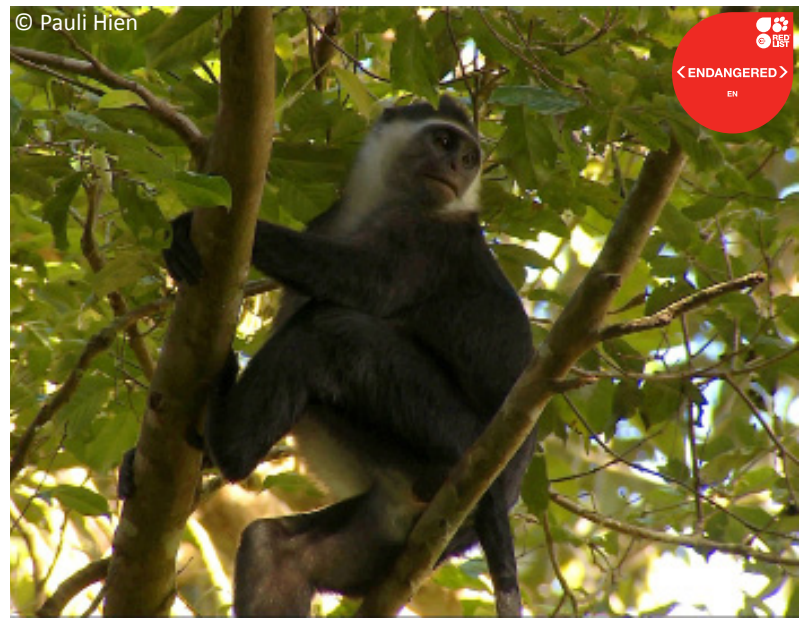

Image 4. Siberut Island Langur Presbytis siberu (2011) 
associated with a rising human population (PHPA 1995) have all led to significant loss of intact forest (and consequently primate habitat) across the Mentawai region (Goeltenboth \& Timotius 1993; Whittaker 2006). Hunting has been a pressure on the local wildlife since the colonization of the archipelago several thousand years ago (Schefold 1992), and since primates were the most abundant large mammals, they became the mainstay of hunting activities (Tilson 1977; WWF 1980). In the absence of other large predators (except possibly pythons and eagles, see, Whitten \& Whitten 1982, Tenaza \& Tilson 1985), anthropogenic hunting has become one of the main causes of primate mortality in the region (Mitchell \& Tilson 1986).

Whilst hunting of primates on the Mentawais is generally acknowledged to be extensive (Whittaker 2006), its impact on the primate populations remains poorly understood. Historically, primate hunting and the consumption of their meat were an important part of the ceremonies and rituals associated with the animistic belief system of the Mentawai people (NooyPalm 1968). The use of simple bow and poison arrow as the predominant hunting tool along with a complex set of customary regulations are believed to have prevented over-exploitation in the past (Mitchell 1982). However, as a result of early missionary influences, government resettlement schemes and the increasing use of modern firearms, traditional attitudes to hunting have progressively eroded (Tenaza 1987; Whittaker 2005). Without the cultural restraints of former times, hunting is now generally accepted as a significant influence on the distribution and abundance of Mentawai primates (Watanabe 1981; Mitchell 1985; Fuentes 2002) and for some species (e.g., Simias) it is even viewed as the single greatest threat (Whittaker 2006). Unfortunately, most of these accounts of hunting in the Mentawais are anecdotal, and where quantitative data are available, they are either limited, based on questionable methodology (i.e., counting of trophy skulls - WWF 1980; Whitten \& Whitten 1982; Mitchell \& Tilson 1986) or on data covering a restricted geographic area on the islands of North and South Pagai (Paciulli 2004).

We conducted an island-wide questionnaire survey on Siberut, the largest and northernmost of the Mentawai Islands, with the objective of gaining greater insight into the attitudes of the indigenous inhabitants to local resource utilization, with particular reference to the practice of primate hunting. In addition to providing socio-demographic data on the survey participants, we were specifically interested in which primates were hunted, the reasons for hunting, current methods, hunting frequencies and whether there was a difference between the island's protected area (Siberut National Park) and the rest of Siberut. From the data gathered, we further attempted an approximation of annual offtake from hunting for Siberut's four primate species. In this way, we hope to generate information required to better gauge the significance of hunting as a threat to Siberut's primate population and thus to support the development of future conservation action (plans) and initiatives for the region's primates.

\section{METHODS}

Three survey teams were sent out to Siberut Island $\left(0.55^{\prime}-1^{0} 55^{\prime} \mathrm{S} \& 98^{0} 35^{\prime}-99^{\circ} 20^{\prime} \mathrm{E}\right)$ from June to July 2012 to undertake questionnaire surveys at 50 villages, the distribution of the survey locations corresponding to the distribution of villages on Siberut. Since only men participate in primate hunting activities (see e.g., Mitchell \& Tilson 1986), we surveyed a total of 400 randomly selected men 18 years or older. All households within a given village were mapped, listed and sample households were then randomly selected using a set interval and a random start-point. A single adult member from each household was chosen for the interview, again on a random basis. Village size was taken into account while undertaking the surveys such that at larger villages ( $>75$ households) 15 interviews were administered, 10 at midsized villages (30-75 households), and five at smaller villages ( $<30$ households).

In order to ensure that the meaning and context of the survey questions were properly understood by the respondents, all interviewers received intensive training during a 3-day workshop that included simulated interviews with workshop participants, test interviews with locals in real-life situations and in-depth discussions of test results. Each team was led by a person with prior survey experience and, to minimize the development of distrust that Mentawai people can exhibit towards nonMentawai visitors, all interviewers were recruited from the Siberut population. In addition "control questions" included in our questionnaire indicated consistency in individual responses, suggesting that truthful answers were generally given.

Data collection was conducted through personal, face-to-face interviews, using a structured questionnaire which included both closed-and open-ended questions relating to (i) household socio-demographics, (ii) natural resource use, and (iii) hunting practices. All interviews 


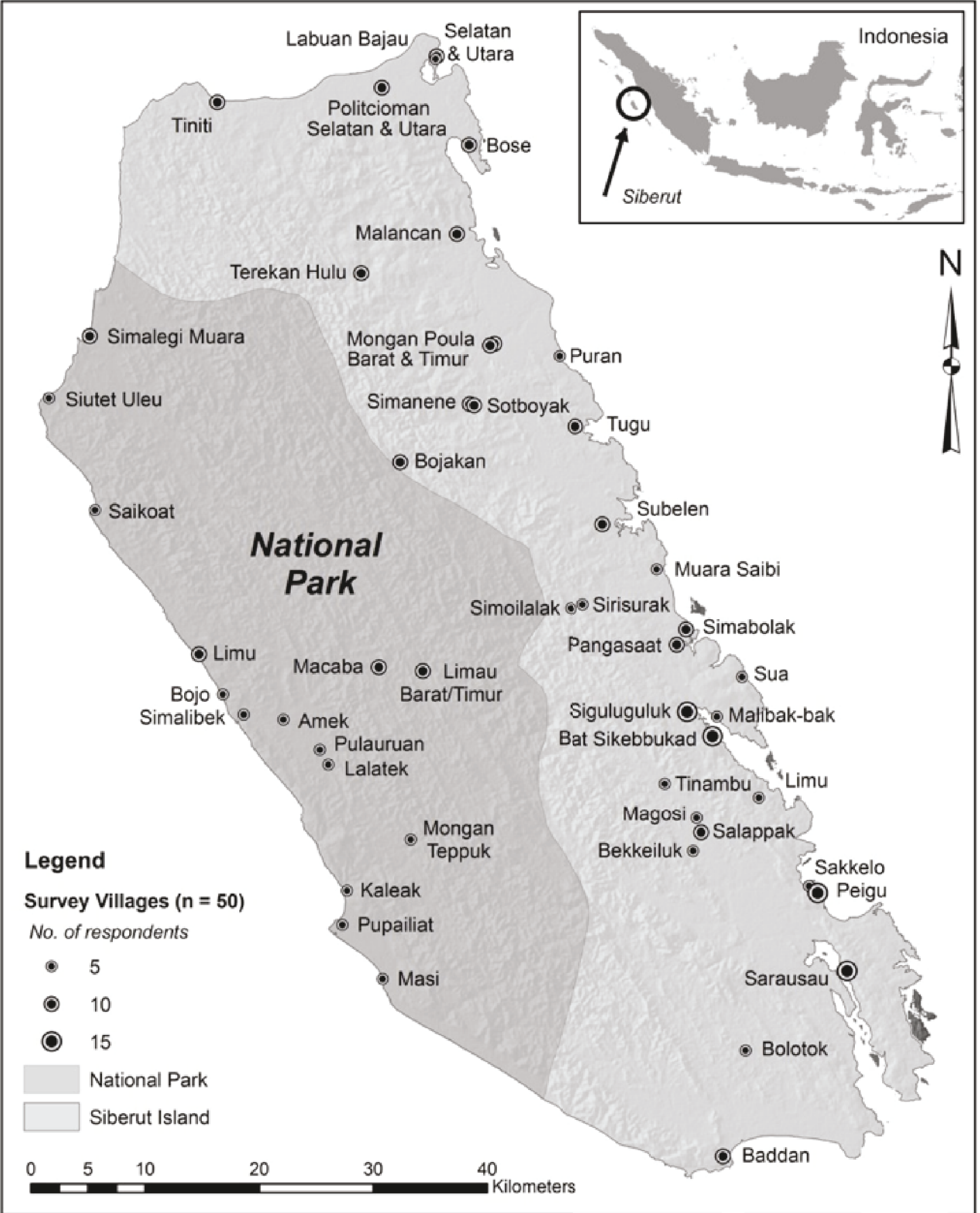

Figure 1. Siberut Island showing all 50 villages visited during the survey as well as the two geographic analysis strata "National Park" (SNP) and "non-National Park" (non-SNP).

were conducted with the consent of the respondents, who were assured confidentiality. Demographic and socioeconomic variables were collected alongside the main survey questions, including age, gender, religion, highest level of formal education, household size and occupation. Of a total of 400 interviewed households, 390 answered all socio-economic, hunting- and conservation-related questions.

Survey data were tabulated in QPSmr Insight V2012.2 and statistical tests were performed using Stata V11. Data were analysed as a full set (Siberut as a whole), and using a geographic stratification with two distinct sub-sets, i.e., a) Siberut National Park (SNP) and b) nonSNP (see Fig. 1) to assess potential differences between 
the protected area and the rest of the island. To test for such differences, chi-square statistics were calculated for nominal categorical variables; in case the expected cell sizes were five or less, Fisher's exact test was applied. We examined ordinal dependent variables using WilcoxonMann-Whitney tests. McNemar's test was applied for analysing species-specific differences in hunting prevalence (which is hunted most), hunting reasons and -methods as well as Wilcoxon signed-rank test to assess differences in hunting frequency (how often hunted). We also used chi-square and Kruskal Wallis tests to evaluate the relationships between socio-economic variables (age, religion, education) and hunting-related variables (hunting reasons, -tools, and -frequency). Significant test results $(p<0.05)$ were followed by logistic regression analyses.

Using information obtained from our questionnaire, we attempted to approximate annual off-take rates per species as follows: the average number of primates per species taken in a 3-month period was multiplied by the total number of respondents still hunting that species. Values were then adjusted to represent primates taken/killed per hunting party instead of per individual since, almost without exception, primates are hunted by groups of several members of an extended family (clan or 'uma'). Based on information gathered by ourselves and provided by K. Meyers and Y. Simalainge (personal communication), we assume a typical hunting party to comprise between four and eight members and accordingly, the data shown in Table 3 represent this range. Values for primates killed per hunting party per three months were then multiplied by four to represent off-take per annum and extrapolated from the 390 respondents to Siberut's total population using government census data (BPSKKM 2011).

\section{RESULTS}

\section{Socio-economics and Resource Use}

Based on our socio-economic data a typical household on Siberut has an average of five members (5.3, range: 1-19), with an average of three children (3.6). As shown in Table 1, survey respondents were mostly of Christian faith (Catholic: 59\%, Protestant: 26\%), with Muslims accounting for $12 \%$ of the sample. The level of education was relatively low, with only $30 \%$ of respondents having secondary or tertiary education (junior high school: $18 \%$, high school and university: $12 \%)$. Over half (52\%) had only elementary education and $18 \%$ were without formal education. Almost everyone (95\%) owned a small garden/field ('ladang') where they grow chocolate $(95 \%)$, coconuts $(84 \%)$, bananas $(76 \%)$, taro $(60 \%)$, sago (51\%), vegetables (19\%) and other crops (cloves, sweet potatoes, areca nut and rubber). Most also kept animals (78\%), mainly chickens (98\%) and pigs (30\%); and less than 9\% owned other animals (cattle, water buffalo, goats). Gathering forest products was an important activity, with about two-thirds of the men (64\%) gathering wood and almost three-quarters (73\%) mentioning other forest products such as rattan (60\%), medicinal plants (24\%), fruit (18\%), and honey (14\%). $14 \%$ said they collect tree bark and roots for poison arrows (hunting). More people carried out hunting $\left(\chi^{2}=44.1 / p<0.001\right)$, animal farming $\left(\chi^{2}=13.6 / p<0.001\right)$, gathering of wood $\left(\chi^{2}=21.4 / p<\right.$ $0.001)$ and other forest products $\left(\chi^{2}=21.7 / p<0.001\right)$, sago processing $\left(\chi^{2}=27.6 / p<0.001\right)$ and river fishing $\left(\chi^{2}\right.$ $=8.0 / p=0.005)$ within SNP than outside it.

\section{Primate Hunting}

Of the 390 respondents across all four survey regions, $38 \%(n=148)$ claimed they have hunted at some point in their lifetime, and 24\%, ( $n=93$ ) reported that they still do. The results for all hunting-specific questions are exclusively based on these 93 respondents. More hunters were above 40 years of age $(60 \%)$ than in the total sample (53\%), although this difference is not statistically significant.

Overall, there were no differences between SNP and the non-SNP area for any of the hunting-related variables (Table 2). Hunters mostly took S. concolor (77\%), $M$. siberu $(71 \%)$ and $P$. potenziani $(68 \%)$ and there were no statistically significant differences between the capture frequencies for these species. H. klossii, on the other hand, was rarely hunted ( $3 \%$ of respondents; $\chi^{2}>60 / p$ $<0.001$ ) and was, therefore, not included in subsequent analyses.

The reasons for primate hunting are similar across species, with general consumption being reported most frequently (between $90 \%$ and $92 \%$ ), followed by cultural/ceremonial reasons (52-56\%) while, recreation, improving one's social status and trade were seldom given as a reason (all $\leq 14 \%$ ).

Poison arrows were the main method for hunting primates throughout Siberut and are used by $84-89 \%$ of all hunters, depending on the species. Older people (40+) used bow and arrow to hunt more often than younger people, which is statistically significant only for $M$. siberu $\left(\chi^{2}=7 / p=0.013\right)$ and $P$. siberu $\left(\chi^{2}=11.5 / p=0.001\right)$. Air rifles with poison pellets were also widely employed (72-75\%). The use of traps/snares differs significantly between the three species. They are mostly used for 
Table 1. Socio economic profile of $\mathbf{n}=\mathbf{3 9 0}$ male respondents across the two analysis regions on Siberut, shown as percentages.

\begin{tabular}{|c|c|c|c|}
\hline \multirow{2}{*}{ Variables } & \multicolumn{2}{|c|}{ Region (n) } & \multirow{2}{*}{$\begin{array}{l}\text { Total } \\
(390)\end{array}$} \\
\hline & $\begin{array}{l}\text { SNP } \\
\text { (94) }\end{array}$ & $\begin{array}{c}\text { Non-SNP } \\
\text { (296) }\end{array}$ & \\
\hline \multicolumn{4}{|l|}{ Age } \\
\hline $18-39$ & 52 & 45 & 47 \\
\hline $40+$ & 48 & 55 & 53 \\
\hline \multicolumn{4}{|l|}{ Education } \\
\hline None & 19 & 17 & 18 \\
\hline Elementary & 50 & 53 & 52 \\
\hline Jun. High school \& higher & 31 & 30 & 30 \\
\hline \multicolumn{4}{|l|}{ Religion* } \\
\hline Catholic & $82^{*}$ & 51 & 59 \\
\hline Protestant & $8^{*}$ & 32 & 26 \\
\hline Muslim & 10 & 13 & 12 \\
\hline Other & 0 & $4^{*}$ & 3 \\
\hline \multicolumn{4}{|l|}{ Activities* } \\
\hline Working in the fields & 99 & 94 & 95 \\
\hline Animal farming & $91 *$ & 73 & 78 \\
\hline Gathering wood & $84^{*}$ & 58 & 64 \\
\hline Gathering other forest products & $90 *$ & 66 & 73 \\
\hline Processing sago & $68^{*}$ & 37 & 45 \\
\hline Fishing (sea) & 24 & 28 & 27 \\
\hline Fishing (rivers) & $26^{*}$ & 13 & 16 \\
\hline Hunting in the forest & $49 *$ & 16 & 24 \\
\hline
\end{tabular}

* Indicates significant differences between regions at the $5 \%$ level (chi ${ }^{2}$ test)

M. siberu (39\% of the hunters; compared to $S$. concolor $\chi^{2}=21.0 / p<0.001 ;$ P. siberu $\chi^{2}=16.0 / p<0.001$ ), less used for $P$. siberu (13\% of the hunters; compared to $M$. siberu $\chi^{2}=7.0 / p<0.001$ ), and hardly used for $S$. concolor (3\%). Similarly, the use of hunting dogs is highest for the macaque $\left(x^{2}=6.4 / p<0.02\right)$.

Although $36-45 \%$ of the current hunters said that they hunted sporadically (specifically in connection to traditional ceremonies), the data suggest that hunting occurred relatively frequently, with $15-20 \%$ reporting that they hunt at least once in three months and 33-37\% reporting that they hunt twice or more within the same period. The hunting frequency neither differs between species nor with respect to age class, level of education or religion (Table 1).

As shown in Table 3, more than $85 \%$ of hunters take three or fewer animals. Most commonly, only a single animal is taken, with average numbers per three months ranging from $1.9-2.3$ for $S$. concolor, $M$. siberu and $P$. siberu); gibbons are hunted very rarely ( 0.33 animals $/ 3$ -
Table 2. Overview of the central questions on primate hunting (figures are percentages), differentiated by species and based on all men currently hunting ( $n=93)$. Responses for hunting reasons, -methods and -frequency are based only on those respondents actually hunting the respective species $(\mathrm{n}<93)$.

\begin{tabular}{|c|c|c|c|c|}
\hline & $\begin{array}{l}\text { Simias } \\
\text { concolor }\end{array}$ & $\begin{array}{c}\text { Presbytis } \\
\text { siberu }\end{array}$ & $\begin{array}{c}\text { Macaca } \\
\text { siberu }\end{array}$ & $\begin{array}{l}\text { Hylobates } \\
\text { klossii }\end{array}$ \\
\hline \multicolumn{5}{|l|}{ Species hunted } \\
\hline \multirow[t]{2}{*}{ Siberut Island } & 77 & 68 & 71 & 3 \\
\hline & $n=72$ & $n=63$ & $n=66$ & $n=3$ \\
\hline \multicolumn{5}{|c|}{ Reasons for hunting } \\
\hline Food source & 90 & 92 & 91 & n.a. \\
\hline Cultural/Ritual & 53 & 52 & 56 & n.a. \\
\hline Recreation & 6 & 8 & 5 & n.a. \\
\hline $\begin{array}{l}\text { Prestige/Social } \\
\text { status }\end{array}$ & 13 & 14 & 11 & n.a. \\
\hline Selling/Income & 4 & 3 & 2 & n.a. \\
\hline \multicolumn{5}{|l|}{ Hunting method } \\
\hline Poison Arrow & 85 & 86 & 89 & n.a. \\
\hline Air rifle & 72 & 75 & 74 & n.a. \\
\hline Dogs* & 26 & 22 & 47 & n.a. \\
\hline Traps/snares* & 3 & 13 & 39 & n.a. \\
\hline \multicolumn{5}{|l|}{ Hunting frequency } \\
\hline Sporadic & 36 & 43 & 45 & n.a. \\
\hline Once in 3 month & 19 & 21 & 17 & n.a. \\
\hline $\begin{array}{l}\text { Twice in } 3 \\
\text { months or more }\end{array}$ & 38 & 29 & 32 & n.a. \\
\hline
\end{tabular}

* Indicates significant differences between species at the $5 \%$ level (McNemar's test \& Wilcoxon test)

month period). Extrapolating these data, and using a range in hunting party size of 4-8 members, we estimate that between 4,860-9,720 primates are killed every year on Siberut, including 1,620-3,240 Simakobu, 1,6803,360 Joja, 1,550-3,100 Bokkoi and 12-24 gibbons.

\section{Attitudes towards primates and forest conservation}

A majority of the respondents (41\%) indicated that primates are now harder to find compared to recent years (Table 4); 31\% report no change and only a minority feel that primates are easier to find now (16\%). Almost $83 \%$ regard primate conservation as important - significantly more so in the National Park $\left(\chi^{2}=5.6 / p=0.018\right)$. Most of the respondents (72\%) believe that the current forest area on Siberut is smaller than some years ago (more pronounced in people living outside the parks borders; $z=2.3 / p=0.021$ ), while $23 \%$ responded that there was no marked change and $1 \%$ reported an increase. Almost all respondents $(97 \%)$ agreed that forest conservation is important. 
Table 3. Number of primates hunted per respondent (household) in a 3-month period, extrapolated annual offtake and estimation of the proportion (\%) of each species removed based on the most recent estimates for the primate population of Siberut Island from Whittaker (2006).

\begin{tabular}{|c|c|c|c|c|c|}
\hline \multirow{2}{*}{ Number of primates } & \multicolumn{5}{|c|}{ No. of hunters taking primates per 3-months } \\
\hline & S. concolor & P. siberu & M. siberu & H. klossii & Total \\
\hline 0 & 6 & 4 & 7 & 2 & 19 \\
\hline 1 & 37 & 28 & 31 & 1 & 97 \\
\hline 2 & 13 & 10 & 14 & 0 & 37 \\
\hline 3 & 8 & 10 & 3 & 0 & 21 \\
\hline 4 & 3 & 3 & 2 & 0 & 8 \\
\hline 5 or more & 5 & 8 & 9 & 0 & 22 \\
\hline Total number of hunters & 72 & 63 & 66 & 3 & 93 \\
\hline Average number of primates/hunter & 1.9 & 2.3 & 2.0 & 0.3 & 6.5 \\
\hline Average 3-monthly off-take & 137 & 142 & 131 & 1 & 411 \\
\hline Corrected average off-take/3 months* & $17-34$ & $18-36$ & $16-33$ & $0.13-0.25$ & $51-103$ \\
\hline Estimated annual off-take (sample) & 69-137 & $71-142$ & $66-131$ & $0.5-1$ & $206-411$ \\
\hline Extrapolated annual off-take (Siberut Island) & $1,620-3,239$ & $1,679-3,385$ & $1,549-3,098$ & $1.2-2.4$ & $4,859-9,719$ \\
\hline Primate population estimates** & $6,000-15,500$ & $1,600-9,500$ & $17,000-30,000$ & $18,000-21,000$ & $42,600-76,000$ \\
\hline Population-based offtake-percentage & $10.4-54 \%$ & $17.7-210 \%$ & $5.2-18.2 \%$ & $0.05-0.1 \%$ & $6.4-22.8 \%$ \\
\hline
\end{tabular}

* - corrected by size range of hunting party (see methods for further description), i.e., size between 4-8 people

** - based on Whittaker 2006

Table 4. Perceptions of the survey respondents regarding trends in primate presence and forest area as well as the importance of primate and forest conservation on Siberut Island, provided as percentages $(n=390)$.

\begin{tabular}{|c|c|c|c|}
\hline \multirow[t]{2}{*}{ Variables } & \multicolumn{2}{|c|}{ Region (n) } & \multirow{2}{*}{$\frac{\text { Total }}{(390)}$} \\
\hline & $\begin{array}{l}\text { SNP } \\
\text { (94) }\end{array}$ & $\begin{array}{c}\text { Non-SNP } \\
(296)\end{array}$ & \\
\hline \multicolumn{4}{|c|}{ Forest area - Trend* } \\
\hline Larger & 0 & 1 & 1 \\
\hline Same & 34 & 20 & 23 \\
\hline Smaller & 64 & 75 & 72 \\
\hline No response & 2 & 4 & 4 \\
\hline \multicolumn{4}{|c|}{ Primate presence - Trends* } \\
\hline Easier to find & 29 & 11 & 16 \\
\hline No change & 26 & 33 & 31 \\
\hline Harder to find & 39 & 42 & 41 \\
\hline No response & 6 & 14 & 12 \\
\hline \multicolumn{4}{|c|}{ Forest conservation } \\
\hline Important & 99 & 96 & 97 \\
\hline Not important & 1 & 1 & 1 \\
\hline No response & 0 & 2 & 2 \\
\hline \multicolumn{4}{|c|}{ Primate conservation* } \\
\hline Important & 79 & 84 & 83 \\
\hline Not important & 12 & 5 & 6 \\
\hline No response & 9 & 11 & 11 \\
\hline
\end{tabular}

* Indicates significant differences between analysis regions at the $5 \%$ level (chi test)

\section{DISCUSSION}

Our results emphasize that hunting is still an integral part of the culture of the Mentawai Islands, and specifically Siberut. It occurs relatively frequently and is geographically widespread, with the majority of the villages (> 75\%) harbouring active hunters. Considering a total population of just under 35,100 in 2010 (BPSKKM 2011), we estimate the hunting community on the island to consist of around 2,270 individuals at the time of our survey.

\section{Hunting of primates}

S. concolor appears to be the hunters' main target, which is in line with previous reports: It is considered by many to be the best tasting species and the easiest to hunt (Tilson 1979; WWF 1980; Mitchell \& Tilson 1986), since its general predator response is to sit still rather than flee (Tilson 1977; WWF 1980). Surprisingly, over $70 \%$ of the respondents target macaques although their meat is generally considered unpalatable (Fuentes 2002). Most likely, the species is hunted because of its tendency to enter the people's ladangs to steal crops and as such would be regarded as a pest (Paciulli 2004). This is also well known for the archipelago's southernmost islands, where macaques (and Presbytis) are regularly poisoned with pesticides for this reason (Tenaza 1991). Conversely, the native gibbon is targeted 
by very few hunters, a finding similar to that of Tenaza \& Tilson (1985), who reported that despite living at higher densities compared to the three other species, gibbons constituted a mere $4 \%$ of the primate skulls counted in the ceremonial houses inside their study area in central Siberut. Beside gibbon meat being considered distasteful (Tilson 1974 in Mitchell \& Tilson 1986; Whittaker 2005), the main reason for low gibbon hunting frequency is probably that they are the most difficult primates to catch. Being exclusively arboreal, they often sleep in liana-free emergent trees, which makes them inaccessible to hunters (Tilson \& Tenaza 1982). Also, they move rapidly in the canopy when alerted and produce loud predator-specific alarm calls, which can potentially alert other primates in the area (Tilson \& Tenaza 1977; Tenaza \& Tilson 1985). Furthermore, religious taboos generally forbade the hunting of $\mathrm{H}$. klossii in former times (Mitchell \& Tilson 1986), and despite the ongoing erosion of cultural tradition, it is plausible that in those places where cultural traditions are not formally observed anymore, traditional values continue to live on as customary practice.

Methods of hunting were similar for all species, except for the high amount of trapping reported for macaques, a finding not entirely surprising, since it is the only primate on Siberut that habitually spends time on the ground (Whitten \& Whitten 1982). More surprising, however, is that, although the use of air-rifles has increased over recent years and is now widespread, bow and poison arrows still remain the primary tool for hunting all four primate species. Whether this is related to the government's 1987 ban on air rifles (although not enforced on Siberut; Tenaza 1988) or to actual preferences and the desire to maintain traditional elements in hunting practice is not clear from our survey. Our finding that hunters under the age of 40 use bows and arrows less often compared with older hunters, suggests however, that traditional practices are indeed on the decline. In this context it is noteworthy that some of our respondents explicitly stated that the rules which used to govern the hunts are less observed nowadays.

It is interesting that consumption was most often given as the reason for hunting and indeed a successful hunt would yield primate flesh as a supplemental source of animal protein. However, given the numbers and frequency of primates hunted, they can only form an occasional part of the local diet, much more important sources of animal protein being fish (incl. shellfish and crustacean) with lesser amounts of pork and chicken (data from present study). Considering that between 36-56 \% of respondents acknowledge they hunt for cultural/ceremonial reasons, it may be that primate flesh still has a more symbolic, cultural value and that eating it on occasion is an important part of Mentawaian social life.

While in other countries primates are often hunted to be sold as 'bushmeat' in local markets (cf. Franzen 2006; Fa \& Brown 2009), on Siberut only 2-3\% of the hunters reported selling primates. Further, of those traded, it remains unclear whether they are being sold for consumption or as pets, although only 1 out of all 390 respondents specifically indicated the use of primates as pets. In this respect, our data does not support the suggestion of Whittaker (2006) that the pet trade is a driver of primate population decline in the Mentawais, at least on Siberut.

In general, differences in our survey data between the National Park and the rest of Siberut were small. Our results show a greater prevalence within the park's borders of hunting, sago processing, gathering of wood and NTFPs, river fishing and animal farming compared to the outside area, suggesting that the park's inhabitants live a more subsistence-based lifestyle. Located on the more remote western side of the island, this would be expected. It is, however, alarming that hunting is actually higher in the park. Considering its division into three land-use zones, with hunting being forbidden in the sanctuary zone and limited by permits in another (traditional use zone; PHPA 1995), we would have expected levels of hunting to be lower compared to the outside. That this is not the case calls for improved hunting related management strategies.

\section{Off-take estimates}

Our figures for off-take are based on an assumption regarding hunting party size, and therefore need to be viewed with a degree of caution. Nevertheless, the estimate of 4,800-9,700 primates per year is useful as it not only represents the first attempt to directly quantify hunting activities on Siberut, but also in indicating that the numbers of primates taken in this way are substantial. The impact that removal on such a scale has on Siberut's primate population as a whole, and more importantly on the individual species, is difficult to assess, as this depends on a variety of interrelated factors including current size and recent trends in the populations of each species, age and sex of animals killed, changes in availability of suitable forest habitat and rate of human population growth and distribution, information on all of which is sparse and unreliable. Using the most recent population estimates for Siberut (Whittaker 2006), our figures indicate between 6 and 22\% (see Table 3) 
of the primate population is lost annually to hunting. Although the gibbons seem to be relatively unaffected by hunting, and the impact on the macaques remains comparatively low, we estimate that no less than 10-17 $\%$ of the estimated populations of the two langur species are removed through hunting activities each year. Furthermore, since most available data indicate that populations of all primates are in decline (e.g., Tenaza 1990; Fuentes 1996; Whittaker 2006; this survey), the impact of hunting is likely to increase in the future, this effect being further exacerbated by continued increases in the human population (ca. $2.2 \%$ growth per annum: BPS 2002; BPSKKM 2011) and associated demands on forest habitat.

\section{Conservation implications}

While our data do not allow robust conclusions about the sustainability of hunting on Siberut, they clearly indicate that hunting of primates is a widespread and frequent activity that is responsible for the removal of substantial numbers of three of the island's four species. At the same time, our results show that hunting is likely to be of little consequence for the local gibbon. In general, our findings underscore the importance of considering hunting and its impact when conducting population viability assessments and in the development of population management plans for Siberut's primates. Although hunting alone may pose little immediate threat, its significance in combination with a continued decline in available primate habitat, further reduction in overall primate population size and an increase in a less-traditionally oriented human population, should not be underestimated and measures to address the impact of hunting on Siberut's primate populations need to be taken now.

Given the cultural value that hunting of primates still has, together with the fact that virtually all of what is hunted is for local use, we support the view presented in earlier reports (WWF 1980; PHPA 1995), that the local conservation challenge is not to eliminate hunting per se, but to establish measures to limit its impact on primate populations. Since attempts to abolish the hunting tradition are bound to incur the anger of the traditional communities and thus prevent further efforts to constructively improve the situation, we advocate a combined approach which would include: (i) lobbying the local government to ban the use and possession of air rifles throughout the archipelago, and confiscate such weapons; (ii) an island-wide campaign to emphasize cultural tradition in order to increase the hunters' inclination to follow traditional practices and taboos, including ceremonial rather than opportunistic hunting; (iii) improving agricultural practices to decrease dependence on primates for animal protein; (iv) active inclusion of locals into conservation projects and environmental tourism ventures on Siberut as guides and field assistants (cf. Corlett 2007) who can act as multipliers for a positive conservation message in their communities; (v) conservation education and outreach targeted at communities in areas of particular importance to primate conservation (e.g., National Park) delivered through local schools, informal groups and village leaders to consolidate the largely positive image that Siberut's human population generally holds of the local primates.

\section{REFERENCES}

Bodmer, R.E., J.F. Eisenberg \& K.H. Redford (1997). Hunting and the Likelihood of Extinction of Amazonian Mammals. Conservation Biology 11(2): 460-466.

BPS - Biro Pusat Statistik (2002). Mentawai dalam Angka. Kabupaten Kepulauan Mentawai,Tuapejat. (Unpublished report).

BPSKKM - Badan Pusat Statistik Kabupaten Kepulauan Mentawai (2011). Kepulauan Mentawai in Figures 2011. Regional Development Planning Board of Kepulauan Mentawai, Tuapejat, Sipora. <http:// mentawaikab.bps.go.id/livebeta/?p=104>. Downloaded on 20.02.2013.

Corlett, R.T. (2007). The impact of hunting on the mammalian fauna of tropical Asian forests." Biotropica 39(3): 292-303; http://dx.doi. org/10.1111/j.1744-7429.2007.00271.x

Dela, J.D.S. (2011). Impact of monkey-human relationships and habitat change on Semnopithecus vetulus nestor in human modified habitats. Journal of the National Science Foundation Sri Lanka 39(4): 365-384; http://dx.doi.org/10.4038/jnsfsr.v39i4.4144

Fa, J.E. \& D. Brown (2009). Impacts of hunting on mammals in African tropical moist forests: a review and synthesis. Mammal Review 39(4): 231-264; http://dx.doi.org/10.1111/j.1365-2907.2009.00149.x

Franzen, M. (2006). Evaluating t he $s$ ustainability o $f$ h unting: a comparison of harvest profiles across three Huaorani communities. Environmental Conservation 33(1): 36-45; http://dx.doi. org/10.1017/S0376892906002712

Fuentes, A. (1996). "Current status and future viability for the Mentawai primates." Primate Conservation 17: 111-116.

Fuentes, A. (2002). Monkeys, humans and politics in the Mentawai Islands: no simple solutions in a complex world, pp. 187-207. In: Fuentes, A. \& L.D. Wolfe (eds.). Primates Face to Face: Conservation Implications of Human-Nonhuman Primate Interactions. Cambridge, Cambridge University Press.

Goeltenboth, F. \& K.H. Timotius (1993). Impact of rainforest destruction - The Siberut Island Case, Sumatra, Indonesia, pp. 425433. In: Edwards, D. S., W.E. Booth \& S. C. Choy. Tropical Rainforest Research - Current Issues. Dordrecht / Boston / London, Kluwer Academic Publishers.

IUCN (2014). IUCN Red List of Threatened Species. Version 2014.2. URL: <www.iucnredlist.org>; Downloaded on 02 August 2014.

Mitchell, A.H. (1982). Siberut Nature Conservation Area, West Sumatra, Management Plan 1983-1988. WWF Report for the Directorate of Nature Conservation Perlindungan dan Pelestarian Alam Republic of Indonesia. Bogor, Indonesia, 121pp.

Mitchell, A.H. (1985). Human predation of primates in the Mentawai Islands, Indonesia. International Journal of Primatology 5(4): 362.

Mitchell, A.H. \& R.L. Tilson (1986). Restoring the balance: traditional 
hunting and primate conservation in the Mentawai Islands, Indonesia, pp. 249-260. In: Else, J.G. \& P.H. Lee (eds). Primate Ecology and Conservation. Cambridge University Press, New York.

Mittermeier, R.A., C. Schwitzer, A.B. Rylands, L.A. Taylor, F. Chiozza, E.A. Williamson \& J. Wallis (eds.) (2012). Primates in Peril: The World's 25 Most Endangered Primates 2012-2014. IUCN/SSC Primate Specialist Group (PSG), International Primatological Society (IPS), Conservation International (CI), and Bristol Conservation and Science Foundation, Bristol, UK, 40pp.

Nooy-Palm, H. (1968). The Culture of the Pagai-Islands and Sipora, Mentawei. Tropical Man 1: 152-241

Paciulli, L.M. (2004). The effects of logging, hunting, and vegetation on the densities of the Pagai, Mentawai Islands primates. PhD Thesis. Stony Brook University New York, 428pp.

PHPA (1995). Siberut National Park Integrated Conservation and Development Management Plan (1995-2020). Volume I: Current Conditions and Evaluation. Chemonics International in association with PT. Indeco Duta Utama and PT. Nadya Karsa Amerta, for Ditjen Perlindungan Hutan dan Pelestarian Alam, Departemen Kehutanan, Republik Indonesia, Jakarta, 119pp.

Schefold, R. (1992). Shamans on Siberut: Mediators between the worlds, pp. 105-117. In: Lindsay, C. Mentawai Shaman: Keeper of the Rain Forest. Aperture, New York.

Tenaza, R.R. (1987). The status of primates and their habitats in their habitats in the Pagai Islands, Indonesia. Primate Conservation 8(104): 110

Tenaza, R.R. (1988). The status of primates and their habitats in their habitats in the Pagai Islands, Indonesia: A progress report. Primate Conservation 9: 146-149.

Tenaza, R.R. (1991). Conservation of the Mentawai Islands' primates, pp. 55-58. In: Ehara, A., T. Kimura, O. Takenaka \& M. Iwamoto (eds.). Primatology Today, Elsevier Science Publishers, Amsterdam.

Tenaza, R. \& R. Tilson (1985). Human predation and Kloss's Gibbon (Hylobates klossii) sleeping trees in Siberut Island, Indonesia. American Journal of Primatology 8(4): 299-308; http://dx.doi. org/10.1002/ajp.1350080405

Tilson, R.L. (1977). Social organization of Simakobu (Nasalis concolor) in Siberut Island, Indonesia. Journal of Mammalogy 58(2): 202-122.

Tilson, R.L. (1979). Der Unbekannte Affe. Das Tier 5: 20-23.

Tilson, R.L. \& R.R. Tenaza (1977). Evolution of long-distance alarm calls in Kloss' Gibbon. Nature 268: 233-235; http://dx.doi. org/10.1038/268233a0

Tilson, R.L. \& R.R. Tenaza (1982). Interspecific spacing between gibbons (Hylobates klossii) and langurs (Presbytis potenziani) on Siberut Island, Indonesia. American Journal of Primatology 2(4) 355-361; http://dx.doi.org/10.1002/ajp.1350020404

Watanabe, K. (1981). Variations in group composition and population density of two sympatric Mentawaian Leaf-Monkeys. Primates 22(2): 145-160; http://dx.doi.org/10.1007/BF02382606

Whittaker, D.J. (2005). Evolutionary genetics of Kloss's Gibbons (Hylobates klossii): Systematics, phylogeography, and conservation (Indonesia). PhD Thesis. Graduate Faculty in Anthropology. City University of New York, New York, 201pp.

Whittaker, D.J. (2006). A Conservation Action Plan for the Mentawai Primates. Primate Conservation 20: 95-105; http://dx.doi. org/10.1896/0898-6207.20.1.95

Whitten, A.J. \& J.E.J. Whitten (1982). Preliminary observations of the Mentawai Macaque on Siberut Island, Indonesia. International Journal of Primatology 3(4): 445-459; http://dx.doi.org/10.1007/ BF02693743

Wilson, D.E. \& D.A. Reeder (eds.) (2005). Mammal species of the world: a geographic and taxonomic reference, $3^{\text {rd }}$ Edition. The John Hopkins University Press, Baltimore, MD, USA, 2142pp.

WWF (1980). Saving Siberut: A Conservation Master Plan. WWF Indonesia Programme, Bogor, Indonesia, 135pp.
Bahasa Indonesia Abstrak: Kepulauan Mentawai (Sumatera Barat Indonesia) memiliki kekayaan satwa dan tanaman endemik termasuk enam jenis primata unik, yang semuanya dalam keadaan terancam sebagai akibat hilangnya habitat serta perburuan. Walaupun perburuan diketahui terjadi dimana-mana, sangat sedikit penelitian yang dilakukan secara sistematis untuk mempelajari skala dan dampaknya terhadap populasi primata di Mentawai. Disini kami melaporkan hasil penelitian yang dilakukan di seluruh Pulau Siberut, pulau terbesar di kepulauan Mentawai, untuk menilai perilaku berburu dalam hal empat spesis primata setempat serta sikap penduduk setempat atas penggunaan sumber daya. Wawancara tatap-muka dilakukan di pertengahan 2012 dengan 390 responden dari 50 desa dengan metode angket tersusun. Secara keseluruhan, kurang-lebih seperempat dari responden (24\%) masih aktif berburu. Pada umumnya mereka berburu Simias concolor (77\%), Macaca siberu (71\%) dan Presbytis siberu (68\%). Hylobates klossii jarang ditargetkan (3\%). Kebanyakan, seekor satwa ditangkap dalam sekali perburuan, dengan rata-rata tiga ekor setiap bulannya, berkisara 1.9-2.3 masing-masing (untuk S. concolor, M. siberu dan P. siberu). Dalam banyak hal, kami menemukan data kami tidak menunjukkan perbedaan antara kawasan terlindung (Taman Nasional Siberut) dan area lainnya di Pulau Siberut, walaupun perburuan jauh lebih sering terjadi didalam wilayah kawasan terlindung. Perkiraan kami atas hasil buruan tahunan menunjukkan bahwa tidak kurang dari 4800 primata diambil setiap tahun (min. $6.4 \%$ dari populasi). Kami berikan rekomendasi/saran bagaimana mengurangi kegiatan berburu sebagai penyebab penurunan populasi.

Author Details: MARCEL C. QUINTEN is a conservation biologist working together with the German Primate Center and the Siberut Conservation Programme on the preservation of the endemic primates of the Mentawai Archipelago. FARQUHAR STIRLING has worked in survey research for more than 40 years, much of that time in Indonesia, and was managing director of Indonesia's largest research firm. He previously designed and analyzed audience research surveys for BBC world service radio. STEFAN SCHWARZE is an agricultural economist currently working as an assistant professor at the Department of Agricultural Economics and Rural Development, Faculty of Agriculture, University of Goettingen. Particular research interests include the adoption and impact of agricultural technologies. YOAN DINATA is a wildlife ecologist from Indonesia with a research focus on the ecology and conservation of the Sumatran Tiger in Kerinci Seblat National Park and West Sumatra; since 2009 he has been running the Kloss Gibbon project of Fauna and Flora International in the Mentawai Islands. J. KEITH HODGES has research interests in evolutionary endocrinology and comparative reproduction in primates.

Author Contributions: MCQ coordinated the survey project, prepared the manuscript and supported survey design and analysis. Principal persons responsible for the latter were FS (design) and SS (analysis). YD coordinated the field teams together with $\mathrm{FS}$, and $\mathrm{KH}$ contributed to the survey planning, data analysis and preparation of the manuscript. 